Article

\title{
Fucoxanthin, A Carotenoid Derived from Phaeodactylum tricornutum Exerts Antiproliferative and Antioxidant Activities In Vitro
}

\author{
Ulrike Neumann ${ }^{1,+}+\mathbb{D}$, Felix Derwenskus ${ }^{2,3,+} \mathbb{C}$, Verena Flaiz Flister ${ }^{1}$, Ulrike Schmid-Staiger ${ }^{2}$, \\ Thomas Hirth ${ }^{4}$ and Stephan C. Bischoff ${ }^{1, *}$ \\ 1 Institute of Clinical Nutrition, University of Hohenheim, Fruwirthstr. 12, 70593 Stuttgart, Germany; \\ ulrike.neumann@uni-hohenheim.de (U.N.); verena.flister@gmail.com (V.F.F.) \\ 2 Fraunhofer Institute for Interfacial Engineering and Biotechnology IGB, Nobelstr. 12, 70569 Stuttgart, \\ Germany; felix.derwenskus@igb.fraunhofer.de (F.D.); ulrike.schmid-staiger@igb.fraunhofer.de (U.S.-S.) \\ 3 Institute of Interfacial Process Engineering and Plasma Technology IGVP, University of Stuttgart, \\ Nobelstr. 12, 70569 Stuttgart, Germany \\ 4 Karlsruhe Institute for Technology, Kaiserstr. 12, 76131 Karlsruhe, Germany; thomas.hirth@kit.edu \\ * Correspondence: bischoff.stephan@uni-hohenheim.de; Tel.: +49-711-459-24101 \\ + Contributed equally.
}

Received: 20 May 2019; Accepted: 17 June 2019; Published: 19 June 2019

\begin{abstract}
Microalgae contain a multitude of nutrients and can be grown sustainably. Fucoxanthin, a carotenoid from Phaeodactylum tricornutum, could have beneficial health effects. Therefore, we investigated the anti-inflammatory, antioxidative and antiproliferative effects of fucoxanthin derived from this diatom in vitro. The effects of purified fucoxanthin on metabolic activity were assessed in blood mononuclear cells and different cell lines. In cell lines, caspase 3/7 activity was also analyzed. Nitrogen monoxide release and mRNA-expression of proinflammatory cytokines were measured. For antioxidant assays, cell free assays were conducted. Additionally, the antioxidant effect in neutrophils was quantified and glutathione was determined in HeLa cells. The results show that neither did fucoxanthin have anti-inflammatory properties nor did it exert cytotoxic effects on mononuclear cells. However, the metabolic activity of cell lines was decreased up to $58 \%$ and fucoxanthin increased the caspase 3/7 activity up to 4.6-fold. Additionally, dose-dependent antioxidant effects were detected, resulting in a $63 \%$ decrease in chemiluminescence in blood neutrophils and a 3.3-fold increase in the ratio of reduced to oxidized glutathione. Our studies show that fucoxanthin possesses antiproliferative and antioxidant activities in vitro. Hence, this carotenoid or the whole microalgae P. tricornutum could be considered as a food or nutraceutical in human nutrition, showcasing beneficial health effects.
\end{abstract}

Keywords: microalgae; Phaeodactylum tricornutum; fucoxanthin; antioxidative; antiproliferative

\section{Introduction}

Microalgae are microscopic small unicellular organisms that are abundant in various habitats around the globe. They can be cultured in open ponds or photobioreactors without the use of arable land and thus represent a promising sustainable alternative to plant-based proteins. They do not only produce high amounts of proteins but are also a good source for fatty acids, and vitamins, which can provide health promoting effects in a human diet. Hence, they can serve as novel functional foods or be incorporated into existing food products $[1,2]$.

The unicellular pennate diatom Phaeodactylum tricornutum exists in three different morphotypes and its genome has been already fully sequenced [3]. The diatom contains a multitude of different 
components that could provide health beneficial effects. These include the omega- 3 fatty acid eicosapentaenoic acid (EPA), polyphenols like (epi-) catechin and oxygenated carotenoids like fucoxanthin [4-8]. Fucoxanthin, a major marine carotenoid, is located in the thylakoids of chloroplasts and forms a light harvesting complex (LHC) with chlorophyll a/c [9,10]. It was shown in several studies, that fucoxanthin from macroalgae possesses health-conducive effects, including anti-inflammatory, antioxidant, antiobesity and anticancer activities [11-15]. Since most of these studies used fucoxanthin derived from macroalgae, only little is known about the health-beneficial effects of fucoxanthin derived from $P$. tricornutum, although this microalga was shown to have a high content of fucoxanthin between 16.5 to $26.1 \mathrm{mg}$ per gram dry matter $(\mathrm{dm})[16,17]$. Thus, diatom biomass can contain up to ten times more fucoxanthin than macroalgae. Additionally, diatoms, different from macroalgae, can be cultivated indoors and outdoors not only during specific seasons but all around the year with a high biomass productivity [18]. It is already demonstrated that they can be produced in various types of different closed photobioreactors, like bubble columns and flat panel airlift bioreactors [19-21]. Hence, P. tricornutum might be a suitable source for the commercial production of fucoxanthin.

The prevalence of diseases linked to oxidative stress and inflammation is constantly increasing in developed countries [22-24]. The occurrence of those diseases can also be linked to the emergence of cancer $[25,26]$. Therefore, research is trying to identify new compounds that could be used to reduce inflammation, oxidative stress, and the viability of cancer cells. Fucoxanthin derived from P. tricornutum might be used as a new nutraceutical, if it also exhibits the health beneficial effects that were already shown for the carotenoid derived from macroalgae.

\section{Materials and Methods}

\subsection{Cultivation of Microalgae and Fucoxanthin Extraction}

P. tricornutum UTEX 640 was cultivated in 180 L Flat-Panel-Airlift photobioreactors in an outdoor pilot scale plant located at the Fraunhofer Center for Chemical-Biotechnological Processes CBP in Leuna, Germany. Modified Mann and Myers medium was used as culture medium as described in Meiser et al. [19,27]. The biomass was disrupted using stirred ball milling (PML-2, Bühler) and freeze-drying prior to fucoxanthin extraction. The cell disruption and extraction method were previously described in detail in Derwenskus et al. [17]. Briefly, Fucoxanthin was extracted from the disrupted biomass by pressurized liquid extraction (ASE 350, Thermo-Fisher) for a static extraction time of $20 \mathrm{~min}$ at $100{ }^{\circ} \mathrm{C}$ and 100 bar using adequate subcritical organic solvents (described in [28]). Subsequently, the fucoxanthin was purified by multiple separation steps using filters $(0.25 \mu \mathrm{m})$ consisting of polytetrafluoroethylene to a final purity of $99.2 \%$ ( $w / w)$ (HPLC). It was compared to a commercial fucoxanthin standard (16337, Sigma-Aldrich) using UHPLC-MS.

It was compared to a commercial fucoxanthin standard (16337, Sigma-Aldrich) using UHPLC-MS.

\subsection{Determination of Fucoxanthin by HPLC and UHPLC-MS}

Fucoxanthin was quantified using the HPLC method described by Gille et al. [28] with slight modifications. Briefly, the purified fucoxanthin was resolved in pure ethanol with BHT $(250 \mathrm{mg} / \mathrm{L})$ and compared to a commercial analytical standard (16337, Sigma-Aldrich, St. Louis, MO, USA) using reverse-phase HPLC with a Suplex pKb 100 column $(5 \mu \mathrm{m}, 250 \times 4.6 \mathrm{~mm}$, Supelco, Bellefonte, PA, USA). Samples (injection volume $5 \mu \mathrm{L}$ ) were analyzed using a HPLC (1200 Infinity, Agilent, Santa Clara, CA, USA) equipped with a multi-wavelength UV detector at $450 \mathrm{~nm}$ and a flow rate of $1 \mathrm{~mL} / \mathrm{min}$. The gradient used for the method is described in detail elsewhere [29].

Additionally, fucoxanthin from P. tricornutum was analyzed and compared to the commercial standard by UHPLC-DAD (1290 Infinity, Agilent Technologies) using a Zorbax Eclipse Plus C18 $(2.1 \times 50 \mathrm{~mm})$ column with a particle size of $1.8 \mu \mathrm{m}$. Mobile phase A contained water with $0.1 \%$ formic acid and mobile phase B consisted of methanol with $0.1 \%$ formic acid. The gradient used is shown in Table 1. The fucoxanthin was detected at $450 \mathrm{~nm}$ and analyzed in a mass spectrometer (LTQ XL, 
Thermo Scientific) using ESI in full scan mode from 200 to $1000 \mathrm{~m} / \mathrm{z}$ at a temperature of $275{ }^{\circ} \mathrm{C}$ and $-9.0 \mathrm{~V}$. The $\mathrm{m} / \mathrm{z}$ values (see supplementary material, S1) were compared to the analytical standard and to literature [30].

Table 1. Solvent gradient for the UHPLC-MS-Method used in this study. Mobile phase A consisted of water with $0.1 \%$ formic acid and mobile phase B was methanol with $0.1 \%$ formic acid.

\begin{tabular}{ccc}
\hline Time [min] & Mobile Phase A [\%] & Mobile Phase B [\%] \\
\hline 0 & 70 & 30 \\
8 & 3 & 97 \\
11 & 3 & 97 \\
11.1 & 70 & 30 \\
14 & 70 & 30 \\
\hline
\end{tabular}

\subsection{Isolation of Human Primary Blood Cells Band Cell Cultures}

Anticoagulated blood was collected from healthy volunteers, approved by the local ethics committee (F-2015-064, Landesärztekammer Baden-Württemberg). Isolation of polymorphonuclear leukocytes (PML) and peripheral blood mononuclear cells (PBMCs) via dextran sedimentation and density gradient centrifugation was conducted as previously described by El Benna \& Dang (2007) [30] and Neumann et al. (2018) [31]. PMLs were resuspended in DPBS, PBMCs in RPMI medium with $10 \%$ fetal calf serum and 1\% penicillin / streptomycin. HepG2 cells were provided by the Max Rubner-Institute (Karlsruhe, Germany). RAW 264.7, HepG2, Caco-2 and HeLa cells were cultured in DMEM with $10 \%$ fetal calf serum and $1 \%$ penicillin / streptomycin.

\subsection{Metabolic Activity}

Metabolic activity was assessed using the tetrazolium dye 3-(4,5-dimethylthiazol-2-yl)-2, 5-diphenyltetrazolium bromide (MTT). PBMCs $\left(3 \times 10^{5}\right.$ cells per well) and RAW 264.7 cells $\left(1 \times 10^{4}\right.$ cells per well) were incubated with fucoxanthin $(0.1,1,10$ and $50 \mu \mathrm{g} / \mathrm{mL}), \beta$-carotene $(1 \mu \mathrm{g} / \mathrm{mL})$, dimethyl sulfoxide (DMSO, $0.1 \%$ ) as solvent control or DMSO (5\%) as positive control for $24 \mathrm{~h}$. Subsequent, MTT assay was conducted as previously described [31].

\subsection{Antiinflammatory Assays}

Nitric oxide (NO) production in RAW 264.7 cells was measured using the Griess assay. Therefore, $5 \times 105$ cells were treated with fucoxanthin $(0.1$ and $1 \mu \mathrm{g} / \mathrm{mL})$ or $\beta$-carotene $(1 \mu \mathrm{g} / \mathrm{mL})$ and stimulated with lipopolysaccharide (LPS, $1 \mu \mathrm{g} / \mathrm{mL}$ ) for $24 \mathrm{~h}$. The level of $\mathrm{NO}$ was measured using the Griess reaction, as previously described [32].

The effects of fucoxanthin on the LPS-induced mRNA expression of the cytokines interleukin(IL-) $1 \beta$, IL-6, tumor necrosis factor $\alpha$ (TNF- $\alpha$ ) and the enzyme cyclooxygenase-2 (COX-2) in PBMCs was measured by quantitative real-time polymerase chain reaction (qRT-PCR). Cells were incubated with fucoxanthin $(0.1,1$ or $10 \mu \mathrm{g} / \mathrm{mL}), \beta$-carotene $(1 \mu \mathrm{g} / \mathrm{mL})$ or DMSO $(0.1 \%)$ as solvent control for $24 \mathrm{~h}$. Cells were stimulated with LPS $(1 \mu \mathrm{g} / \mathrm{mL})$ for $6 \mathrm{~h}$. The mRNA expression was measured as formerly described [31].

\subsection{Antioxidant Assays}

Total phenolics content (TPC) was determined using the Folin-Ciocalteu method [33] with minor modifications. In a 96-well microplate, $30 \mu \mathrm{L}$ of fucoxanthin $(0.1,1$ or $10 \mu \mathrm{g} / \mathrm{mL})$ were mixed with $150 \mu \mathrm{L}$ Folin-Ciocalteu reagent (diluted $1 / 10$ in water) and $120 \mu \mathrm{L}$ sodium carbonate solution (75 g/L). To obtain an individual blank, samples were mixed with $120 \mu \mathrm{L}$ sodium carbonate solution and $150 \mu \mathrm{L}$ water. After $2 \mathrm{~h}$ in the dark at room temperature, the absorbance was measured at $765 \mathrm{~nm}$ with a BioTek Synergy HT plate reader (BioTek Instruments, Winooski, VT, USA). Gallic acid was used to 
establish a calibration curve $(30-580 \mu \mathrm{M})$ and results are expressed as gallic acid equivalents (GAE) per gram dry matter $(\mathrm{dm})$.

The ferric reducing antioxidant power (FRAP) assay was performed in accordance to the method of Benzie and Strain [34]. An individual blank was measured for each sample. Ferrous sulphate solutions were used for calibration $(50-1000 \mu \mathrm{M})$ and the results are expressed as mmol Fe ${ }^{2+}$ per gram $\mathrm{dm}$.

For the 2,2-diphenyl-1-picrylhydrazyl (DPPH) assay a calibration curve was obtained by using $\mathrm{DPPH}$ concentrations in the range of $0-100 \mu \mathrm{M}$. A DPPH solution was freshly prepared in methanol. $150 \mu \mathrm{L}$ DPPH $(0.1 \mathrm{MM})$ were mixed with $50 \mu \mathrm{L}$ fucoxanthin $(0.1,1,10$ or $50 \mu \mathrm{g} / \mathrm{mL}), 150 \mu \mathrm{L}$ methanol instead of DPPH were used for blank measurement. The percentage inhibition was calculated using the following formula:

$$
\% \text { Inhibition }=\left(\mathrm{OD}_{\mathrm{DPPH}}-\mathrm{OD}_{\text {Sample }}\right) / \mathrm{OD}_{\mathrm{DPPH}} \times 100
$$

The half maximal inhibitory concentration (IC50) was calculated by linear regression, plotting the percentage inhibition against the different extract concentrations.

The glutathione (GSH) to glutathione disulfide (GSSG) ratio as a marker for oxidative stress was determined using the GSH/GSSG-Glo ${ }^{\mathrm{TM}}$ Assay (Promega, Mannheim, Germany). $2 \times 104 \mathrm{HeLa}$ cells were incubated with fucoxanthin $(0.1,1,10$ and $50 \mu \mathrm{g} / \mathrm{mL}), \beta$-carotene $(1 \mu \mathrm{g} / \mathrm{mL})$, DMSO $(0.1 \%)$ as solvent control or menadione $(40 \mu \mathrm{M})$ as control for $24 \mathrm{~h}$.

$2^{\prime}, 7^{\prime}$-dichlorofluorescin (DCF) fluorescence and ROS production using luminol chemiluminescence were measured in human PMLs. For DCF fluorescence $100 \mu \mathrm{L}$ of freshly drawn blood were incubated with $2^{\prime}, 7^{\prime}$-dichlorofluorescin diacetate $(20 \mu \mathrm{M})$ at $37^{\circ} \mathrm{C}$ for $15 \mathrm{~min}$. Lipopolysaccharide $(10 \mathrm{ng} / \mathrm{mL})$ and fucoxanthin $(0.1,1,10$ or $50 \mu \mathrm{g} / \mathrm{mL})$ or $\beta$-carotene $(1 \mu \mathrm{g} / \mathrm{mL})$ were added for $1 \mathrm{~h}$ at $37^{\circ} \mathrm{C}$. Cells were then stimulated with $\mathrm{N}$-formylmethionyl-leucyl-phenylalanine (fMLP, 500nM). The reaction was stopped after $5 \mathrm{~min}$ by placing the samples on ice. After red blood cell lysis using the BD FACS lysing solution according to the manufacturer's instructions, DCF fluorescence was measured with a BD FACS Canto II (BD Biosciences, Becton, Dickinson and Company, San Jose, CA, USA). The percentage of fluorescent PMLs was calculated using the BD FACS Diva Software.

In luminol assays, PMLs were incubated with fucoxanthin $(0.1,1,10$ and $50 \mu \mathrm{g} / \mathrm{mL}), \beta$-carotene $(1 \mu \mathrm{g} / \mathrm{mL})$, DMSO $(0.1 \%)$ as solvent control or menadione $(40 \mu \mathrm{M})$ as control. The assay was conducted as previously described [35] and cells were stimulated with phorbol 12-myristate 13-acetate (PMA, $100 \mathrm{ng} / \mathrm{mL}$ ). Chemiluminescence was measured in a Berthold-Biolumat LB937 (Berthold Technologies Co., Bad Wildbad, Germany) at $37^{\circ} \mathrm{C}$ for $15 \mathrm{~min}$. Percentage inhibition of luminescence was calculated using the area under the curve (AUC) values.

\subsection{Cytotoxic and Apoptotic Assays}

MTT assays were conducted with Caco-2, HeLa and Hep G2 cells to assess cytotoxic activity of fucoxanthin on cancer cells. Cells were incubated with fucoxanthin $(0.1,1,10$ and $50 \mu \mathrm{g} / \mathrm{mL})$, $\beta$-carotene $(1 \mu \mathrm{g} / \mathrm{mL})$, DMSO $(0.1 \%)$ or staurosporine $(1 \mu \mathrm{M})$ for $48 \mathrm{~h}$, as described elsewhere [32]. For apoptotic properties, the caspase-glo@3/7 assay (Promega, Mannheim, Germany) was conducted according to the manufacturer's instructions.

\subsection{Statistics}

Data are expressed as mean \pm standard error of the mean (SEM) in graphs or \pm standard deviation (SD) in tables. Graphs were generated using GraphPad Prism 5 (La Jolla, CA, USA), statistics were done using IBM SPSS Statistics 25 (IBM Corp., Armonk, NY, USA), graphs. Normal distribution was tested using the Shapiro-Wilk test. One-way analysis of variance (ANOVA) was used to evaluate statistic significant differences $(p<0.05)$ between groups. The equality of variances was tested utilizing 
Levene's test. For equal variances, Tukey's HSD post hoc test was used; for unequal variances, Dunnett's T3 post hoc test3.

\section{Results}

\subsection{Metabolic Activity}

For PBMCs, only the positive control with a final concentration of 5\% DMSO led to a significant decrease in metabolic activity analyzed using the MTT assay. Fucoxanthin up to a concentration of $50 \mu \mathrm{g} / \mathrm{ml}$ did not influence the metabolic activity (Table 2). For RAW 264.7, however, a decrease in metabolic activity was shown for the positive control and the highest fucoxanthin concentration tested (50 $\mu \mathrm{g} / \mathrm{mL}$, Table 2$)$. Hence, the following anti-inflammatory assays were only conducted with non-cytotoxic concentrations.

Table 2. Effects of fucoxanthin from P. tricornutum, vehicle control (DMSO, 0.1\%), positive control (DMSO, 5\%) and $\beta$-carotene on metabolic activity of PBMCs and RAW 264.7 cells. Data are presented as mean $\pm \operatorname{SD}(n=4-6)$.

\begin{tabular}{cccc}
\hline & {$[\mu \mathrm{g} / \mathrm{mL}]$} & \multicolumn{2}{c}{ Metabolic Activity [\%] } \\
\hline & & PBMCs & RAW 264.7 \\
\hline Vehicle control & & 100 & 100 \\
Positive control & 50 & $104.7 \pm 14.16$ & $20.88 \pm 6.33^{* *}$ \\
Fucoxanthin & 10 & $98.76 \pm 5.38$ & $73.28 \pm 9.60$ \\
& 1 & $95.25 \pm 3.84$ & $89.64 \pm 13.76$ \\
$\beta$-carotene & 0.1 & $88.35 \pm 14.13$ & $93.12 \pm 5.09$ \\
& 1 & $87.65 \pm 13.47$ & $80.30 \pm 13.09$ \\
\hline
\end{tabular}

Asterisks mark significant differences to vehicle control as analyzed by ANOVA with Dunnett's T3 post hoc test $\left({ }^{*}<0.05,{ }^{* *}<0.01,{ }^{* * *}<0.001\right)$.

\subsection{Antiinflammatory Effects}

To analyze the anti-inflammatory effects of fucoxanthin, the NO production of RAW 264.7 cells was measured, and mRNA-expressions of inflammatory cytokines were determined in PBMCs (Table 3). Neither fucoxanthin nor $\beta$-carotene showed anti-inflammatory effects in the tested concentrations (Table 3). Additionally, no pro-inflammatory effect was seen in unstimulated cells (Table 3).

Table 3. Effects of fucoxanthin from P. tricornutum, vehicle control (DMSO, 0.1\%) and $\beta$-carotene on relative mRNA expression of pro-inflammatory cytokines in PBMCs and on NO production in RAW 264.7 cells. Data are presented as mean \pm SD $(n=5-7)$.

\begin{tabular}{cccccc}
\hline & {$[\mu \mathrm{g} / \mathrm{mL}]$} & IL-1 $\beta[\%]$ & IL-6 [\%] & TNF $\alpha[\%]$ & NO $[\mu M]$ \\
\hline Vehicle control & & PBMCs & PBMCs & PBMCs & RAW 264.7 \\
Fucoxanthin & & 100 & 100 & 100 & $59.66 \pm 7.59$ \\
& 10 & $110.1 \pm 26.55$ & $99.15 \pm 26.14$ & $160.4 \pm 68.13$ & $56.53 \pm 6.58$ \\
B-carotene & 1 & $97.65 \pm 18.09$ & $92.10 \pm 22.18$ & $133.3 \pm 60.35$ & $60.84 \pm 7.65$ \\
Vehicle control, & 0.1 & $101.3 \pm 18.29$ & $122.5 \pm 32.23$ & $133.9 \pm 55.50$ & $59.21 \pm 7.69$ \\
unstimulated & 1 & $75.07 \pm 44.36$. & $104.2 \pm 57.37$ & $158.7 \pm 80.90$ & $59.84 \pm 7.10$ \\
Fucoxanthin, unstimulated & 10 & $0.2 \pm 0.1$ & $0.1 \pm 0.1$ & $5.6 \pm 5.7$ & $0.0 \pm 0.0$ \\
$\beta$-carotene, unstimulated & 1 & $0.3 \pm 0.5$ & $0.1 \pm 0.04$ & $5.1 \pm 6.2$ & $0.03 \pm 0.1$ \\
\hline
\end{tabular}

No differences between stimulated groups and no differences between unstimulated groups were found by ANOVA $(p<0.05)$. Abbreviations: IL interleukin; TNF tumor necrosis factor, NO nitrogen monoxide. 


\subsection{Antioxidant Effects}

Various assays were conducted to analyze the antioxidant properties of fucoxanthin. In the DPPH assay, fucoxanthin had an IC50 value of $201.2 \pm 21.4 \mu \mathrm{g} / \mathrm{mL}$, while the value for ascorbic acid was $70.3 \pm 18.7 \mu \mathrm{g} / \mathrm{mL}$ and for astaxanthin $79.32 \pm 18.10 \mu \mathrm{g} / \mathrm{mL}$. Due to low antioxidant effects, an IC50 for $\beta$-carotene could not be calculated. Results of the FRAP assay show that fucoxanthin is equivalent to $64.74 \pm 3.93 \mathrm{mmol} \mathrm{Fe}^{2+}$ per gram dm, $\beta$-carotene to $6.55 \pm 0.33$ and astaxanthin to $63.97 \pm 6.79 \mathrm{mmol}$ $\mathrm{Fe}^{2+}$ per gram.

Neither fucoxanthin nor $\beta$-carotene showed effects on the DCF fluorescence of PMLs (data not shown). Menadione decreased the GSH/GSSG ratio. However, according to statistical analysis this change was not significant $(p=0.09)$. Fucoxanthin in the highest concentration $(50 \mu \mathrm{g} / \mathrm{mL})$ increased the ratio significantly (Figure 1A). Lower concentrations, however, showed no effects. Luminol chemiluminescence was measured to evaluate the antioxidant properties of fucoxanthin in PMLs. The results are depicted in Figure 1B and show that menadione decreased the luminescence by $96 \%$, fucoxanthin by $63 \%$ at $50 \mu \mathrm{g} / \mathrm{mL}$. The antioxidant effect is dose-response dependent.
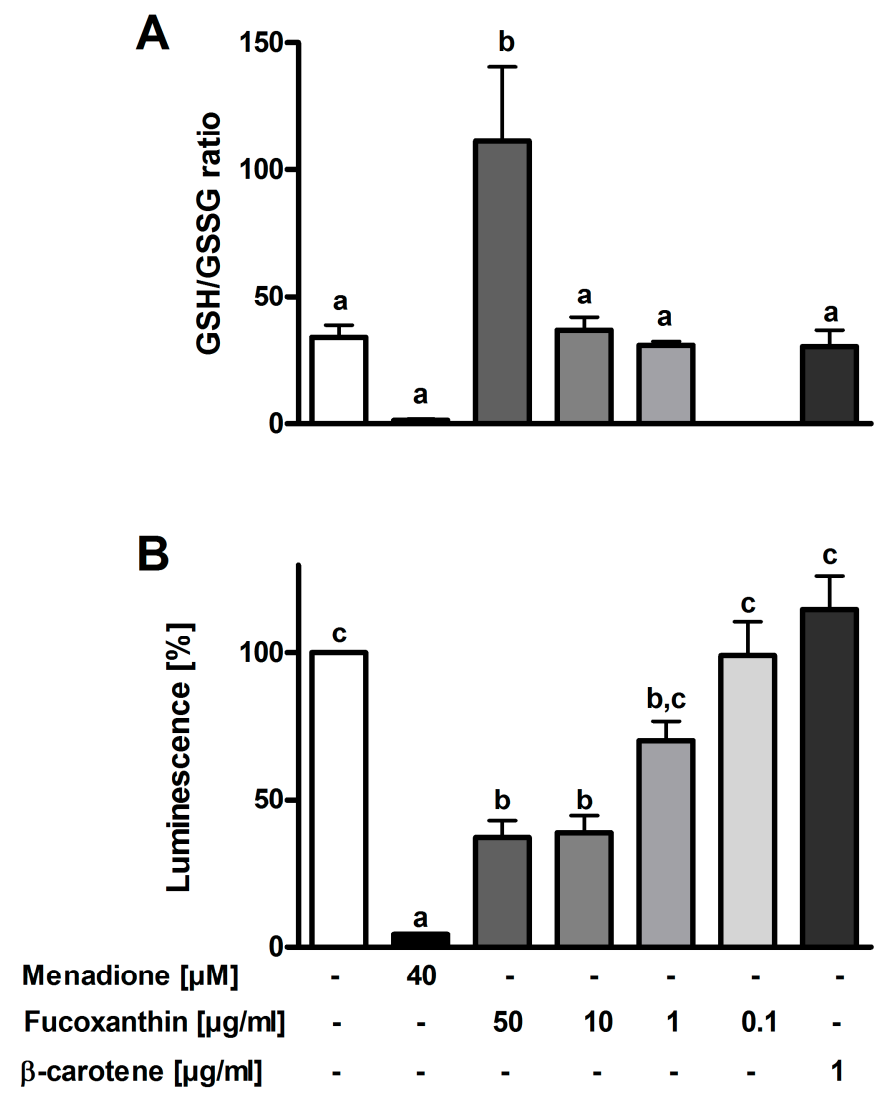

Figure 1. Effects of fucoxanthin from P. tricornutum on GSH to GSSG ratio in HeLa cells (A) and on luminol chemiluminescence in freshly isolated PMLs (B) $(n=3-5)$. Different letters represent significantly different groups (ANOVA followed by Tukey post hoc test for GSH/GSSG assay or with Dunnett's T3 post hoc test for luminol chemiluminescence, $p<0.05)$. Abbreviations: GSH glutathione, GSSG glutathione disulfide.

\subsection{Cytotoxic and Apoptotic Effects}

Fucoxanthin was able to reduce the metabolic activity of Hep G2, HeLa and Caco-2 cells in a dose-dependent manner (Figure 2A-C). An inhibitory effect of up to $58 \%$ was measured in Hep G2 cells. In HeLa and Caco-2 cells, the effect was stronger than that of the positive control with a final concentration of 5\% DMSO. In order to evaluate if the decrease in metabolic activity is linked 
to apoptosis, the caspase 3/7 activity was determined. The results show that fucoxanthin led to a dose-dependent increase in caspase 3/7 activity (Figure 2D-F). A 4.6-fold increase in caspase activity was measured in HeLa cells for the highest fucoxanthin concentration. $50 \mu \mathrm{g} / \mathrm{mL}$ of the carotenoid led to a higher caspase $3 / 7$ activity than $1 \mu \mathrm{M}$ staurosporine in all tested cell cultures.

A

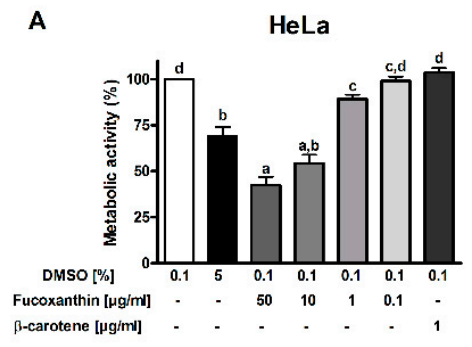

D

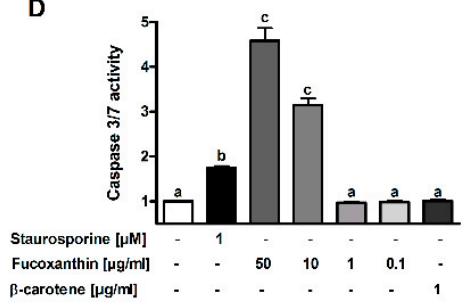

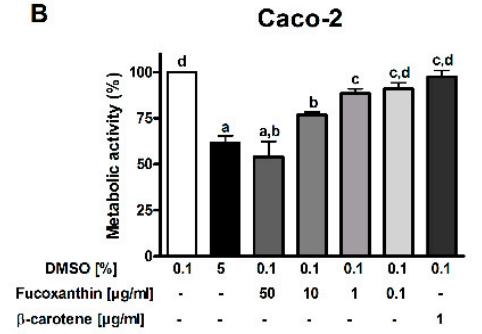

$\mathbf{E}$

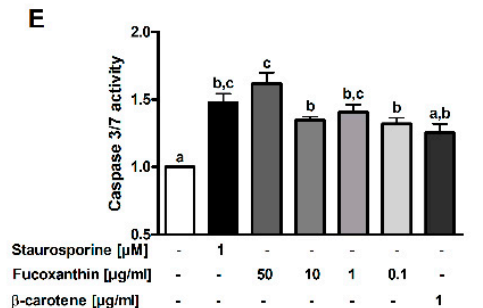

C
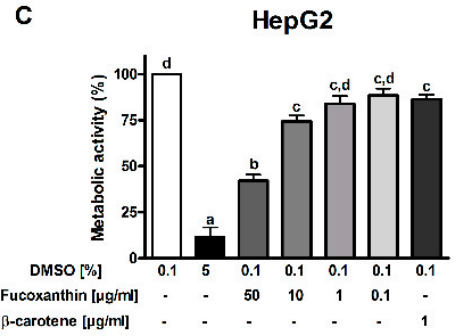

F

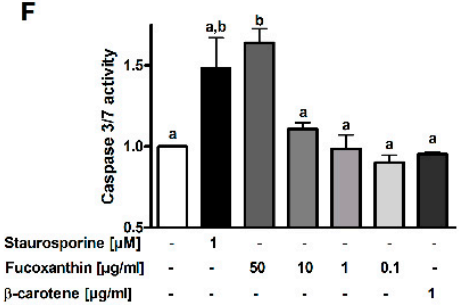

Figure 2. Effects of fucoxanthin from P. tricornutum on metabolic activity of HeLa (A), Caco-2 (B) and HepG2 (C) cells $(n=4-6)$. Cells were incubated for 48 hours, DMSO (5\%) was used as a positive control. Caspase 3/7 activity as a marker for apoptosis was assessed in HeLa (D), Caco-2 (E) and HepG2 (F) cells $(n=4)$. Here, staurosporine $(1 \mu \mathrm{M})$ was used as a positive control. Different letters mark significant differences (ANOVA followed by Tukey post hoc test for D or with Dunnett's T3 post hoc test, $p<0.05$ ).

\section{Discussion}

Fucoxanthin, a major marine carotenoid that is up to now obtained from macroalgae, was successfully extracted from the microalgae P. tricornutum. In this study, we found that fucoxanthin had no influence on the metabolic activity of PBMCs, which was also reported by Ishikawa et al. [36]. This leads to the assumption that fucoxanthin, up to concentrations of $50 \mu \mathrm{g} / \mathrm{mL}$, has no cytotoxic effects on these cells. However, the carotenoid had a cytotoxic effect on the mouse macrophage cell line RAW 264.7 at $50 \mu \mathrm{g} / \mathrm{mL}$. This is not concordant to a study by Islam et al. (2013), who only reported a reduced cell viability at much higher doses of fucoxanthin [37].

This study found no effects of fucoxanthin on the NO production of LPS-stimulated RAW 264.7 cells. A study by Islam et al. (2013) supports these findings [37]. Authors showed anti-inflammatory effects only at higher concentrations [37]. However, other studies were able to show a dose-dependent inhibition of NO production by fucoxanthin at lower concentrations [12,38,39]. Here, we also reported that the carotenoid had no effect on the mRNA-expression of pro-inflammatory cytokines in human PBMCs. This is also not concordant to the study by Heo et al. (2010), who showed an inhibitory effect on the mRNA expression in RAW 264.7 cells [12]. Yet, to date, no studies on the anti-inflammatory effects of fucoxanthin on human primary blood cells have been published. It is noteworthy that all mentioned studies utilized fucoxanthin extracted from seaweeds. Therefore, it can be assumed that the carotenoid from P. tricornutum might have different effects or that the measured effects in other studies are based on impurities resulting from extraction.

Fucoxanthin showed strong antioxidant effects in cell-free and cell-based assays. The IC50 concentration of fucoxanthin with $201 \mu \mathrm{g} / \mathrm{mL}$ in the DPPH assay was higher than that reported by Sachindra et al. (2007) [40]. The higher values might be caused by differences in extraction or on the origin of the carotenoid. As previously described, $\beta$-carotene showed no DPPH radical scavenging activity [41]. Antioxidant effects of ascorbic acid, however, were stronger in FRAP and DPPH assays. The FRAP assay revealed that the antioxidant effects of fucoxanthin extracted from P. tricornutum does 
not significantly differ from that of astaxanthin, a carotenoid with strong antioxidant effects derived from the red algae Haematococcus pluvialis which is already successfully commercialized [42,43]. Both, fucoxanthin as well as astaxanthin showed a strong antioxidant effect in the FRAP assay compared to $\beta$-carotene.

In the DCF fluorescence assay, neither fucoxanthin nor $\beta$-carotene showed antioxidant effects while the luminol assay revealed dose-dependent antioxidant properties of fucoxanthin. The DCF assay is used for the intracellular detection of ROS, especially H2O2 [44]. Luminol, on the other hand, can detect the sum of extra- and intracellular ROS, especially those generated by the myeloperoxidase [45]. Hence, it can be assumed that fucoxanthin is either inhibiting the myeloperoxidase activation or quenching the bactericidal hypochlorite produced by this enzyme. Fucoxanthin was also able to increase the GSH level in HeLa cells, which was already shown by a study in human keratinocytes [46]. GSH as an antioxidant is able to scavenge ROS; the ratio of GSH to GSSG is often used as a marker for oxidative stress. A multitude of diseases is linked to a decreased GSH to GSSG ratio, including Alzheimer's and Parkinson's disease [47-49]. Fucoxanthin could help to increase reduced GSH and hence ameliorate the negative effects of oxidative stress.

Although fucoxanthin had no effect on the metabolic activity of human blood cells, a dose-dependent influence on different carcinoma cell lines was shown. For Caco-2 cells and different cell lines, this was already shown previously [50-52]. To analyze if the reduced metabolic activity is linked to an increased apoptosis of cells, we also measured the caspase 3/7 activity. An increase in activity was shown for all cells, leading to the conclusion that fucoxanthin from P. tricornutum is able to induce apoptosis in different cancer cells. Kim et al. (2010) were able to show, that the induced apoptosis is caused by the formation of ROS by fucoxanthin [51]. The authors state that the production of intracellular $\mathrm{H}_{2} \mathrm{O}_{2}$ and superoxide in the carcinoma cells triggers the apoptosis. This is, however, inconsistent with the antioxidant effects of the carotenoid that was shown in this study. On the other hand, Kotake-Nara et al. (2005) reported that the induced apoptosis is not accompanied by the production of ROS and caused by the loss of mitochondrial membrane potential [53]. It is assumed that oxidative stress is linked to the initiation and promotion of cancer [25]. ROS might lead to DNA damages and hence lead to uncontrolled cell proliferation and decreased apoptosis in cancer cells. On the other hand, antitumor drugs often function by producing ROS that induce oxidative stress in tumor cells and lead to cell death [54]. The role of antioxidants in tumor therapy is therefore a controversial issue. Some studies show that antioxidants can promote the outcome of therapy, while others show negative effects [54,55].

In summary, we were able to show antioxidant and antiproliferative but no anti-inflammatory effects of the carotenoid fucoxanthin extracted from the microalgae P. tricornutum. Fucoxanthin was able to inhibit the oxidative burst in human PMLs, scavenge radicals and increase the GSH to GSSG ratio. Additionally, the metabolic activity was decreased, and apoptosis increased by the carotenoid. This leads to the conclusion that fucoxanthin or the whole microalgae biomass, including fucoxanthin in high amounts, could be considered in nutrition in order to ameliorate the effects of diseases linked to oxidative stress. Additionally, fucoxanthin could help to support traditional cancer treatment because of its beneficial health effects. Human trials are needed in future to further support these suggestions.

Supplementary Materials: The following are available online at http://www.mdpi.com/2076-3921/8/6/183/s1, Figure S1: UHPLC-MS spectra of a commercial fucoxanthin standard (A) and fucoxanthin derived from the diatom $P$. tricornutum (B) showing the specific $\mathrm{m} / \mathrm{z}$-values of precursor ions $(\mathrm{m} / \mathrm{z}=659.6[\mathrm{M}+\mathrm{H}]+; 681.5[\mathrm{M}+\mathrm{Na}]+)$ of fucoxanthin and related daughter ions $(\mathrm{m} / \mathrm{z}=641.8$ and 581.9). Abbreviations: $\mathrm{m} / \mathrm{z}$ mass-to-charge ratio.

Author Contributions: Conceptualization, U.N., F.D., U.S.-S., T.H. and S.C.B.; methodology, U.N. and F.D.; software, F.D.; formal analysis, U.N. and F.D.; investigation, U.N., V.F.F. and F.D.; writing-original draft preparation, U.N., F.D. and S.C.B.; writing-review and editing, V.F.F., U.S.-S. and T.H.; visualization, U.N. and F.D.; supervision, U.S.-S., T.H. and S.C.B.

Funding: This work was supported by a grant to SCB and FD from the Ministry for Science, Research and Art within the Bioeconomy research Program of Baden-Württemberg (Az: 33-7533-10-5/91/1 and Az: 33-7533-10-5-93, 
BÖBW-105B). Furthermore, the authors acknowledge additional support from the bioeconomy graduate program BBW ForWerts.

Acknowledgments: The authors would like to thank the Max Rubner-Institute (Karlsruhe, Germany) for providing the HepG2 cell line.

Conflicts of Interest: The authors declare no conflict of interest.

\section{References}

1. Matos, Â.P. The Impact of microalgae in food science and technology. J. Am. Oil Chem Soc. 2017, 94, 1333-1350. [CrossRef]

2. Caporgno, M.P.; Mathys, A. Trends in microalgae incorporation into innovative food products with potential health benefits. Front. Nutr. 2018, 5, 58. [CrossRef] [PubMed]

3. Bowler, C.; Allen, A.E.; Badger, J.H.; Grimwood, J.; Jabbari, K.; Kuo, A.; Maheswari, U.; Martens, C.; Maumus, F.; Otillar, R.P.; et al. The Phaeodactylum genome reveals the evolutionary history of diatom genomes. Nature 2008, 456, 239-244. [CrossRef] [PubMed]

4. Andrianasolo, E.H.; Haramaty, L.; Vardi, A.; White, E.; Lutz, R.; Falkowski, P. Apoptosis-inducing galactolipids from a cultured marine diatom, Phaeodactylum tricornutum. J. Nat. Prod. 2008, 71, 1197-1201. [CrossRef] [PubMed]

5. Desbois, A.P.; Mearns-Spragg, A.; Smith, V.J. A fatty acid from the diatom Phaeodactylum tricornutum is antibacterial against diverse bacteria including multi-resistant Staphylococcus aureus (MRSA). Mar. Biotechnol. 2009, 11, 45-52. [CrossRef] [PubMed]

6. Foo, S.C.; Yusoff, F.M.; Ismail, M.; Basri, M.; Yau, S.K.; Khong, N.M.H.; Chan, K.W.; Ebrahimi, M. Antioxidant capacities of fucoxanthin-producing algae as influenced by their carotenoid and phenolic contents. J. Biotechnol. 2017, 241, 175-183. [CrossRef] [PubMed]

7. Ha, A.W.; Na, S.J.; Kim, W.K. Antioxidant effects of fucoxanthin rich powder in rats fed with high fat diet. Nutr. Res. Pract. 2013, 7, 475-480. [CrossRef] [PubMed]

8. Rico, M.; López, A.; Santana-Casiano, J.M.; Gonzàlez, A.G.; Gonzàlez-Dàvila, M. Variability of the phenolic profile in the diatom Phaeodactylum tricornutum growing under copper and iron stress. Limnol. Oceanogr. 2013, 58, 144-152. [CrossRef]

9. Caron, L.; Douady, D.; Quinet-Szely, M.; de Goër, S.; Berkaloff, C. Gene structure of a chlorophyll a/c-binding protein from a brown alga: Presence of an intron and phylogenetic implications. J. Mol. Evol. 1996, 43, 270-280. [CrossRef]

10. Veith, T.; Büchel, C. The monomeric photosystem I-complex of the diatom Phaeodactylum tricornutum binds specific fucoxanthin chlorophyll proteins (FCPs) as light-harvesting complexes. Biochim. Biophys. Acta Bioenerg. 2007, 1767, 1428-1435. [CrossRef]

11. Maeda, H.; Hosokawa, M.; Sashima, T.; Murakami-Funayama, K.; Miyashita, K. Anti-obesity and anti-diabetic effects of fucoxanthin on diet-induced obesity conditions in a murine model. Mol. Med. Rep. 2009, 2, 897-902. [CrossRef] [PubMed]

12. Heo, S.-J.; Yoon, W.-J.; Kim, K.-N.; Ahn, G.-N.; Kang, S.-M.; Kang, D.-H.; Affan, A.; Oh, C.; Jung, W.-K.; Jeon, Y.-J. Evaluation of anti-inflammatory effect of fucoxanthin isolated from brown algae in lipopolysaccharide-stimulated RAW 264.7 macrophages. Food Chem. Toxicol. 2010, 48, 2045-2051. [CrossRef] [PubMed]

13. Kang, M.-J.; Kim, S.M.; Jeong, S.-M.; Choi, H.-N.; Jang, Y.-H.; Kim, J.-I. Antioxidant effect of Phaeodactylum tricornutum in mice fed high-fat diet. Food Sci. Biotechnol. 2013, 22, 107-113. [CrossRef]

14. Wang, L.; Zeng, Y.; Liu, Y.; Hu, X.; Li, S.; Wang, Y.; Li, L.; Lei, Z.; Zhang, Z. Fucoxanthin induces growth arrest and apoptosis in human bladder cancer T24 cells by up-regulation of p21 and down-regulation of mortalin. Acta Biochim. Biophys. Sin. 2014, 46, 877-884. [CrossRef] [PubMed]

15. Mei, C.; Zhou, S.; Zhu, L.; Ming, J.; Zeng, F.; Xu, R. Antitumor effects of laminaria extract fucoxanthin on lung cancer. Mar. Drugs 2017, 15, 39. [CrossRef] [PubMed]

16. Kim, S.M.; Jung, Y.-J.; Kwon, O.-N.; Cha, K.H.; Um, B.-H.; Chung, D.; Pan, C.-H. A potential commercial source of fucoxanthin extracted from the microalga Phaeodactylum tricornutum. Appl. Biochem. Biotechnol. 2012, 166, 1843-1855. [CrossRef] [PubMed] 
17. Derwenskus, F.; Metz, F.; Gille, A.; Schmid-Staiger, U.; Briviba, K.; Schließmann, U.; Hirth, T. Pressurized extraction of unsaturated fatty acids and carotenoids from wet Chlorella vulgaris and Phaeodactylum tricornutum biomass using subcritical liquids. Glob. Bioenergy 2019, 11, 335-344. [CrossRef]

18. Steinrücken, P.; Prestegard, S.K.; de Vree, J.H.; Storesund, J.E.; Pree, B.; Mjøs, S.A.; Erga, S.R. Comparing EPA production and fatty acid profiles of three Phaeodactylum tricornutum strains under western Norwegian climate conditions. Algal Res. 2018, 30, 11-22. [CrossRef]

19. Meiser, A.; Schmid-Staiger, U.; Trösch, W. Optimization of eicosapentaenoic acid production by Phaeodactylum tricornutum in the flat panel airlift (FPA) reactor. J. Appl. Phycol. 2004, 16, 215-225. [CrossRef]

20. Mirón, A.S.; Garcıa, M.C.C.; Gómez, A.C.; Camacho, F.G.; Grima, E.M.; Chisti, Y. Shear stress tolerance and biochemical characterization of Phaeodactylum tricornutum in quasi steady-state continuous culture in outdoor photobioreactors. Biochem. Eng. J. 2003, 16, 287-297. [CrossRef]

21. Silva Benavides, A.M.; Torzillo, G.; Kopecký, J.; Masojídek, J. Productivity and biochemical composition of Phaeodactylum tricornutum (Bacillariophyceae) cultures grown outdoors in tubular photobioreactors and open ponds. Biomass Bioenergy 2013, 54, 115-122. [CrossRef]

22. Bonomini, F.; Tengattini, S.; Fabiano, A.; Bianchi, R.; Rezzani, R. Atherosclerosis and oxidative stress. Histol. Histopathol. 2008, 23, 381-390. [CrossRef] [PubMed]

23. Stamp, L.K.; Khalilova, I.; Tarr, J.M.; Senthilmohan, R.; Turner, R.; Haigh, R.C.; Winyard, P.G.; Kettle, A.J. Myeloperoxidase and oxidative stress in rheumatoid arthritis. Rheumatology 2012, 51, 1796-1803. [CrossRef] [PubMed]

24. Molodecky, N.A.; Soon, I.S.; Rabi, D.M.; Ghali, W.A.; Ferris, M.; Chernoff, G.; Benchimol, E.I.; Panaccione, R.; Ghosh, S.; Barkema, H.W.; et al. Increasing incidence and prevalence of the inflammatory bowel diseases with time, based on systematic review. Gastroenterology 2012, 142, 46-54.e42. [CrossRef] [PubMed]

25. Reuter, S.; Gupta, S.C.; Chaturvedi, M.M.; Aggarwal, B.B. Oxidative stress, inflammation, and cancer: How are they linked? Free Radic. Biol. Med. 2010, 49, 1603-1616. [CrossRef] [PubMed]

26. Siegel, R.L.; Miller, K.D.; Jemal, A. Cancer statistics, 2016. CA Cancer J. Clin. 2016, 66, 7-30. [CrossRef] [PubMed]

27. Mann, J.E.; Myers, J. On pigments, growth, and photosynthesis of Phaeodactylum tricornutum. J. Phycol. 1968, 4, 349-355. [CrossRef] [PubMed]

28. Derwenskus, F.; Schmid-Staiger, U.; Bringmann, C. Verfahren zum Erhalt von Fucoxanthin und Fettsäuren aus Algenbiomasse (EN: Process for the recovery of fatty acids and fucoxanthin from algae biomass). DE-Patent Akz 102019202570.6, 26 February 2019.

29. Gille, A.; Hollenbach, R.; Trautmann, A.; Posten, C.; Briviba, K. Effect of sonication on bioaccessibility and cellular uptake of carotenoids from preparations of photoautotrophic Phaeodactylum tricornutum. Food Res. Int. 2019, 118, 40-48. [CrossRef] [PubMed]

30. Zhang, X.; Ibrahim, Y.M.; Chen, T.-C.; Kyle, J.E.; Norheim, R.V.; Monroe, M.E.; Smith, R.D.; Baker, E.S. Enhancing biological analyses with three dimensional field asymmetric ion mobility, low field drift tube ion mobility and mass spectrometry ( $\mu$ FAIMS/IMS-MS) separations. Analyst 2015, 140, 6955-6963. [CrossRef]

31. Neumann, U.; Louis, S.; Gille, A.; Derwenskus, F.; Schmid-Staiger, U.; Briviba, K.; Bischoff, S.C. Anti-inflammatory effects of Phaeodactylum tricornutum extracts on human blood mononuclear cells and murine macrophages. J. Appl. Phycol. 2018, 30, 2837-2846. [CrossRef]

32. El-Benna, J.; Dang, P.M.-C. Analysis of protein phosphorylation in human neutrophils. Methods Mol. Biol. 2007, 412, 85-96. [CrossRef] [PubMed]

33. Singleton, V.L.; Rossi, J.A. Colorimetry of total phenolics with phosphomolybdic-phosphotungstic acid reagents. Am. J. Enol. Vitic. 1965, 16, 144-158.

34. Benzie, I.F.; Strain, J.J. The ferric reducing ability of plasma (FRAP) as a measure of "antioxidant power": The FRAP assay. Anal. Biochem. 1996, 239, 70-76. [CrossRef] [PubMed]

35. Bachoual, R.; Talmoudi, W.; Boussetta, T.; Braut, F.; El-Benna, J. An aqueous pomegranate peel extract inhibits neutrophil myeloperoxidase in vitro and attenuates lung inflammation in mice. Food Chem. Toxicol. 2011, 49, 1224-1228. [CrossRef]

36. Ishikawa, C.; Tafuku, S.; Kadekaru, T.; Sawada, S.; Tomita, M.; Okudaira, T.; Nakazato, T.; Toda, T.; Uchihara, J.-N.; Taira, N.; et al. Anti-adult T-cell leukemia effects of brown algae fucoxanthin and its deacetylated product, fucoxanthinol. Int. J. Cancer 2008, 123, 2702-2712. [CrossRef] [PubMed] 
37. Islam, M.N.; Ishita, I.J.; Jin, S.E.; Choi, R.J.; Lee, C.M.; Kim, Y.S.; Jung, H.A.; Choi, J.S. Anti-inflammatory activity of edible brown alga Saccharina japonica and its constituents pheophorbide a and pheophytin a in LPS-stimulated RAW 264.7 macrophage cells. Food Chem. Toxicol. 2013, 55, 541-548. [CrossRef] [PubMed]

38. Shiratori, K.; Ohgami, K.; Ilieva, I.; Jin, X.-H.; Koyama, Y.; Miyashita, K.; Yoshida, K.; Kase, S.; Ohno, S. Effects of fucoxanthin on lipopolysaccharide-induced inflammation in vitro and in vivo. Exp. Eye Res. 2005, 81, 422-428. [CrossRef]

39. Kim, K.-N.; Heo, S.-J.; Yoon, W.-J.; Kang, S.-M.; Ahn, G.; Yi, T.-H.; Jeon, Y.-J. Fucoxanthin inhibits the inflammatory response by suppressing the activation of NF- $\mathrm{KB}$ and MAPKs in lipopolysaccharide-induced RAW 264.7 macrophages. Eur. J. Pharm. 2010, 649, 369-375. [CrossRef]

40. Sachindra, N.M.; Sato, E.; Maeda, H.; Hosokawa, M.; Niwano, Y.; Kohno, M.; Miyashita, K. Radical scavenging and singlet oxygen quenching activity of marine carotenoid fucoxanthin and its metabolites. $J$. Agric. Food Chem. 2007, 55, 8516-8522. [CrossRef]

41. Müller, L.; Fröhlich, K.; Böhm, V. Comparative antioxidant activities of carotenoids measured by ferric reducing antioxidant power (FRAP), ABTS bleaching assay ( $\alpha$ TEAC), DPPH assay and peroxyl radical scavenging assay. Food Chem. 2011, 129, 139-148. [CrossRef]

42. Lorenz, R.T.; Cysewski, G.R. Commercial potential for Haematococcus microalgae as a natural source of astaxanthin. Trends Biotechnol. 2000, 18, 160-167. [CrossRef]

43. Vigani, M.; Parisi, C.; Rodríguez-Cerezo, E.; Barbosa, M.J.; Sijtsma, L.; Ploeg, M.; Enzing, C. Food and feed products from micro-algae: Market opportunities and challenges for the EU. Trends Food Sci. Technol. 2015, 42, 81-92. [CrossRef]

44. Dikalov, S.I.; Harrison, D.G. Methods for detection of mitochondrial and cellular reactive oxygen species. Antioxid. Redox Signal. 2014, 20, 372-382. [CrossRef] [PubMed]

45. Kirchner, T.; Möller, S.; Klinger, M.; Solbach, W.; Laskay, T.; Behnen, M. The impact of various reactive oxygen species on the formation of neutrophil extracellular traps. Mediat. Inflamm. 2012, 2012, 849136. [CrossRef] [PubMed]

46. Zheng, J.; Piao, M.J.; Kim, K.C.; Yao, C.W.; Cha, J.W.; Hyun, J.W. Fucoxanthin enhances the level of reduced glutathione via the Nrf2-mediated pathway in human keratinocytes. Mar. Drugs 2014, 12, 4214-4230. [CrossRef] [PubMed]

47. Owen, J.B.; Butterfield, D.A. Measurement of oxidized/reduced glutathione ratio. Methods Mol. Biol. 2010, 648, 269-277. [CrossRef] [PubMed]

48. Sian, J.; Dexter, D.T.; Lees, A.J.; Daniel, S.; Agid, Y.; Javoy-Agid, F.; Jenner, P.; Marsden, C.D. Alterations in glutathione levels in Parkinson's disease and other neurodegenerative disorders affecting basal ganglia. Ann. Neurol 1994, 36, 348-355. [CrossRef] [PubMed]

49. Sechi, G.; Deledda, M.G.; Bua, G.; Satta, W.M.; Deiana, G.A.; Pes, G.M.; Rosati, G. Reduced intravenous glutathione in the treatment of early Parkinson's disease. Prog Neuropsychopharmacol. Biol. Psychiatry 1996, 20, 1159-1170. [CrossRef]

50. Kotake-Nara, E.; Sugawara, T.; Nagao, A. Antiproliferative effect of neoxanthin and fucoxanthin on cultured cells. Fish. Sci. 2005, 71, 459-461. [CrossRef]

51. Kim, K.-N.; Heo, S.-J.; Kang, S.-M.; Ahn, G.; Jeon, Y.-J. Fucoxanthin induces apoptosis in human leukemia HL-60 cells through a ROS-mediated Bcl-xL pathway. Toxicol. Toxicol. In Vitro 2010, 24, 1648-1654. [CrossRef]

52. Kumar, S.; Hosokawa, M.; Miyashita, K. Fucoxanthin: A marine carotenoid exerting anti-cancer effects by affecting multiple mechanisms. Mar. Drugs 2013, 11, 5130-5147. [CrossRef] [PubMed]

53. Kotake-Nara, E.; Terasaki, M.; Nagao, A. Characterization of apoptosis induced by fucoxanthin in human promyelocytic leukemia cells. Biosci. Biotechnol. Biochem. 2005, 69, 224-227. [CrossRef] [PubMed]

54. Mut-Salud, N.; Álvarez, P.J.; Garrido, J.M.; Carrasco, E.; Aránega, A.; Rodríguez-Serrano, F. Antioxidant intake and antitumort Therapy: Toward nutritional recommendations for optimal results. Oxid. Med. Cell Longev. 2016, 2016, 6719534. [CrossRef] [PubMed]

55. Thyagarajan, A.; Sahu, R.P. Potential contributions of antioxidants to cancer therapy: Immunomodulation and radiosensitization. Integr. Cancer 2018, 17, 210-216. [CrossRef] [PubMed]

(C) 2019 by the authors. Licensee MDPI, Basel, Switzerland. This article is an open access article distributed under the terms and conditions of the Creative Commons Attribution (CC BY) license (http://creativecommons.org/licenses/by/4.0/). 